\title{
Characterization of Bifidobacterium species in feaces of the Egyptian fruit bat: Description of $B$. vespertilionis sp. nov. and B. rousetti sp. nov.
}

\author{
Monica Modesto ${ }^{\mathrm{a}, 1}$, Maria Satti ${ }^{\mathrm{b}, 1}$, Koichi Watanabe ${ }^{\mathrm{c}, \mathrm{d}}$, Edoardo Puglisi ${ }^{\mathrm{e}}$, \\ Lorenzo Morelli $^{\mathrm{e}}$, Chien-Hsun Huang ${ }^{\mathrm{d}}$, Jong-Shian Liou ${ }^{\mathrm{d}}$, Mika Miyashita ${ }^{\mathrm{f}}$, \\ Tomohiko Tamura $^{\mathrm{f}}$, Satomi Saito ${ }^{\mathrm{f}}$, Koji Mori ${ }^{\mathrm{f}}$, Lina Huang ${ }^{\mathrm{d}}$, Piero Sciavilla ${ }^{\mathrm{a}}$, \\ Camillo Sandri $^{\mathrm{g}}$, Caterina Spieziog ${ }^{\mathrm{g}}$, Francesco Vitali ${ }^{\mathrm{h}}$, Duccio Cavalieri ${ }^{\mathrm{h}}$, \\ Giorgia Perpetuini ${ }^{\mathrm{i}}$, Rosanna Tofalo ${ }^{\mathrm{i}}$, Andrea Bonetti ${ }^{\mathrm{a}}$, Masanori Arita ${ }^{\mathrm{j}, \mathrm{k}}$, \\ Paola Mattarelli ${ }^{\mathrm{a}, *}$ \\ a Department of Agricultural Sciences, University of Bologna, Viale Fanin 44, 40127 Bologna, Italy \\ b Department of Genetics, SOKENDAI University (National Institute of Genetics), Yata 1111, Mishima, Shizuoka 411-8540, Japan \\ ${ }^{c}$ Department of Animal Science and Technology, National Taiwan University, Taipei, Taiwan \\ ${ }^{\mathrm{d}}$ Bioresource Collection and Research Center, Food Industry Research and Development Institute, Hsinchu, Taiwan \\ e Department for Sustainable Food Processes, Faculty of Agricultural, Food and Environmental Sciences, UniversitaC̀attolica del Sacro Cuore, Via Emilia \\ Parmense 84, 29122 Piacenza, Italy \\ f Biological Resource Center (NBRC), National Institute of Technology and Evaluation (NITE), 2-5-8, Kazusakamatari, Kisarazu, Chiba 292-0818, Japan \\ $\mathrm{g}$ Department of Animal Health Care and Management, Parco Natura Viva - Garda Zoological Park, Bussolengo, Verona, Italy \\ $\mathrm{h}$ Department of Biology, University of Florence, Florence, Italy \\ ${ }^{i}$ Faculty of Bioscience and Technology for Food, Agriculture and Environment, University of Teramo, Teramo, Italy \\ j RIKEN Center for Sustainable Resource Science, 1-7-22 Suehiro, Tsurumi, Yokohama, Kanagawa 230-0045, Japan \\ ${ }^{\mathrm{k}}$ Bioinformation and DDBJ Center, National Institute of Genetics, Yata 1111, Mishima, Shizuoka 411-8540, Japan
}

\section{A R T I C L E I N F O}

\section{Article history:}

Received 15 May 2019

Received in revised form 18 August 2019

Accepted 20 August 2019

\section{Keywords:}

New species

Bifidobacterium

Bifidobacterium vespertilionis sp. nov.

Bifidobacteriumrousetti sp. nov.

Rousettus aegyptiacus

\begin{abstract}
A B S T R A C T
Fifteen bifidobacterial strains were obtained from faeces of Rousettus aegyptiacus; after grouping them by RAPD PCR only eight were selected and characterized. Analysis of 16S rRNA and of five housekeeping ( $h s p 60, r p o \mathrm{~B}, c l p C, d n a \mathrm{~J}, d n a \mathrm{G}$ ) genes revealed that these eight strains were classified into five clusters: Cluster I (RST 8 and RST $16^{\mathrm{T}}$ ), Cluster II (RST $9^{\mathrm{T}}$ and RST 27), Cluster III (RST 7 and RST 11), Cluster IV (RST 19), Cluster V (RST 17) were closest to Bifidobacterium avesanii DSM $100685^{\mathrm{T}}$ (96.3\%), Bifidobacterium callitrichos DSM $23973^{\mathrm{T}}$ (99.2\% and 99.7\%), Bifidobacterium tissieri DSM $100201^{\mathrm{T}}$ (99.7 and 99.2\%), Bifidobacterium reuteri DSM $23975^{\mathrm{T}}(98.9 \%)$ and Bifidobacterium myosotis DSM $100196^{\mathrm{T}}(99.3 \%)$, respectively. Strains in Cluster I and strain RST 9 in Cluster II could not be placed within any recognized species while the other ones were identified as known species. The average nucleotide identity values between two novel strains, RST $16^{\mathrm{T}}$ and RST $9^{\mathrm{T}}$ and their closest relatives were lower than $79 \%$ and $89 \%$, respectively. In silico DNA-DNA hybridization values for those closest relatives were 32.5 and $42.1 \%$, respectively. Phenotypic and genotypic tests demonstrated that strains in Cluster I and RST $9^{\mathrm{T}}$ in Cluster II represent two novel species for which the names Bifidobacterium vespertilionis sp. nov. $\left(\right.$ RST $16^{\mathrm{T}}=\mathrm{BCRC} 81138^{\mathrm{T}}=\mathrm{NBRC}$ $113380^{\mathrm{T}}=\mathrm{DSM} 106025^{\mathrm{T}} ;$ RST $8=\mathrm{BCRC} 81135=$ NBRC 113377$)$ and Bifidobacterium rousetti sp. nov. (RST $9^{\mathrm{T}}=$ BCRC $81136^{\mathrm{T}}=$ NBRC $113378^{\mathrm{T}}=$ DSM $106027^{\mathrm{T}}$ ) are proposed.
\end{abstract}

(c) 2019 Elsevier GmbH. All rights reserved.
Of all living mammals, bats are extraordinary and unique given their peculiar adaptations [28]. They are the only mammals that

\footnotetext{
* Corresponding author at: Department of Agricultural Sciences, University of Bologna, Viale Fanin 44, 40127 Bologna, Italy.

E-mail address: paola.mattarelli@unibo.it (P. Mattarelli).

1 These authors contributed equally.
}

can perform real active flight, which is essential for their biology [14] and this characteristic gave the bat order its scientific name - Chiroptera, or hand-wing in Greek $[11,8]$. They have evolved to thrive in diverse ecological niches across the globe [28] and can feed on insects, small mammals, fish, blood, nectar, fruit, and pollen [27]. 
Bats perform key ecosystem services, pollinating crop species in the tropics (e.g., bats pollinate the flowers of agave, making possible the production of tequila) as well as dispersing seeds $[1,14]$.

$[1,28]$. Bats are able to migrate over long distances, creating opportunities for diverse exposure and widespread dissemination of microbes [29].

The Egyptian fruit-bat Rousettus aegyptiacus (body mass: $140-160 \mathrm{~g}$ ) is widely distributed in tropical and subtropical regions of Africa, and Asia. Its northernmost distribution reaches southern Turkey. This bat consumes a variety of wild and cultivated fruits such as Ficus retusa and F. sycomorus (fig), Melia azedarach (chinaberry), Phoenix dactylifera (date), mango and banana and therefore is a potential seed disperser $[13,5]$.

From the anatomical standpoint, Rousettus aegyptiacus has a relatively short intestine, not differentiated into small and large parts and with no observed cecum or appendix; consequently, the duration of the intestinal pass is approximately $40 \mathrm{~min}[11,12]$.

Studies on the microbial ecology of gut microbiota in bats are limited and such information is necessary in determining the ecological significance of these hosts [11].

There are relatively fewer studies investigating the bacterial microbiota in bats with respect to dietary habits of bats. Except a few [11,12], majority of the studies have used culture based approach to study the bacterial communities associated with the bat intestinal tract. These have led to the identification of different bacteria such as Salmonella, Shigella, Enterobacter, Yersinia and many other enteric pathogens from the bat digestive tract. Different sources used for bacterial isolation and identification includes urine, guano and intestinal content or intestine $[1,7,11]$.

At the time of writing, there is no study investigating the presence and the distribution of Bifidobacterium species in fruit bats. Several studies have suggested the importance of isolating and identifying novel strains of the genus Bifidobacterium from various animals, including humans, in order to understand how they are mostly distributed [17,19] and, especially, which are their phenotypic and genotypic characteristics, thus allowing the reconstruction of a more robust bifidobacterial phylogeny.

Therefore, the objective of this study was the characterization of bifidobacterial isolates derived from the faeces of Egyptian fruit bat (Rousettus aegyptiacus).

In March 2017, fresh guanos from the captive colony of the Egyptian fruit bat housed under semi-natural conditions in Parco Natura Viva - Garda Zoological Park (Bussolengo, Verona, Italy), were collected from the ground using a sterile spoon by the animal-care staffs (keepers) during their routine cleaning of the enclosure, put into a sterile plastic tube and stored under anaerobic conditions in an anaerobic jar (Merck) at $4{ }^{\circ} \mathrm{C}$, and were taken promptly to the laboratory (within $2 \mathrm{~h}$ ). The anaerobic atmosphere was obtained using the GasPak EZ Anaerobic Pouch system (BD).

Animals were free from intestinal infections and did not receive antibiotics or probiotics for two months before samples were collected. Their diet consisted mostly of fruit.

For isolation and enumeration of bifidobacteria, aliquots of approximately $1-2 \mathrm{~g}$ of faecal sample were serially 10 -fold diluted with Peptone Water (Merck) supplemented with L-cysteine hydrochloride $(0.5 \mathrm{~g} / \mathrm{L})$. Aliquots of $1 \mathrm{ml}$ from each dilution (from $10^{-1}$ down to $10^{-9}$ ) were inoculated onto MRS (Difco) agar supplemented with L-cysteine hydrochloride $(0.5 \mathrm{~g} / \mathrm{L})$, acetic acid $(1 \mathrm{ml} / \mathrm{L})$ (Merck) and mupirocin (100 mg/L) (Applichem) [21]. Plates were incubated in anaerobic conditions, at $37^{\circ} \mathrm{C}$ for $48-72 \mathrm{~h}$. The anaerobic atmosphere was obtained using the GasPak EZ Anaerobic Pouch system. After incubation, results showed the presence of bifidobacteria, with a colony count number of $4.6 \log _{10} \mathrm{CFU} \mathrm{g}{ }^{-1}$ faeces. Therefore, morphologically different colonies were randomly picked and re-streaked for several generations in order to isolate purified individual bacterial strains.
Isolates were suspended in a $10 \%(\mathrm{w} / \mathrm{v})$ sterile skim milk solution, supplied with lactose (3\%) and yeast extract (0.3\%), and kept both freeze dried and frozen at $-120^{\circ} \mathrm{C}$ until further analysis.

A total of 15 strains were obtained, namely: RST 1, RST 2, RST 3, RST 4, RST 5, RST 7, RST 8, RST 9, RST 11, RST 12, RST 16, RST 17, RST 19, RST 26 and RST 27. For discrimination of the isolates, RAPD-PCR fingerprintings were carried out by using BOXA1R primer (5'-CTACGGCAAGGCGACGCTGACG$\left.3^{\prime}\right)$, ERIC1 (5'-ATGTAAGCTCCTGGGGATTCAC-3') and ERIC2 (5'-AAGTAAGTGACTGGGGTGAGCG-3') primers, as previously described [18,19]. Based on the resulting BOX-PCR and ERIC banding profiles, the isolates were categorized into six groups: Group I (RST 1, RST 2, RST 3, RST 4, RST 5, RST 8, RST 12, RST 16 and RST 26), Group II (RST9T ), Group III (RST 7 and RST 11), Group IV (RST 19), Group V (RST 17) and Group VI (RST 27) (Supplementary Figs. S1 and S2). One or wherever possible two representative strains for each group were selected and a total of eight strains were chosen (RST 8 and RST $16^{\mathrm{T}}$ for Group I, RST $9^{\mathrm{T}}$ for Group II, RST 7 and RST 11 for Group III, RST 19 for Group IV, RST 17 for Group V and RST 27 for Group VI) for 16S rRNA gene sequencing as described by Michelini et al. [16].

The 16S rRNA gene sequences (1400 bp) of strains and of their closest relatives retrieved from the DDBJ/GenBank/EMBL databases were aligned using CLUSTAL Omega in a CLC Sequence Viewer $(1328 \mathrm{nt})$. A phylogenetic tree based on a total of 81 partial $16 \mathrm{~S}$ rRNA gene sequences, including those of members of the genus Bifidobacterium was reconstructed with the maximum-likelihood method [3] and the evolutionary distances were computed by nucleotide model of GTR CAT. The tree was constructed using RaxML version 8.2.7 [25] and rooted with Scardovia inopinata JCM $12537^{\mathrm{T}}$. The statistical reliability of the tree was evaluated by the bootstrap analysis of 1000 replicates with the algorithm Bootstrap rapid hill climbing algorithm. The tree was visualized using FigTree [22].

Comparative analysis of the 16S rRNA gene sequence revealed that these eight strains were classified into five clusters: Cluster I (RST 8, RST $16^{\mathrm{T}}$ ), Cluster II (RST $9^{\mathrm{T}}$ and RST 27), Cluster III (RST 7, RST 11), Cluster IV (RST 19), Cluster V (RST 17). Strains in Cluster I (RST 8, RST $16^{\mathrm{T}}$ ) were the closest to Bifidobacterium avesanii (96.30\% similarity), strains in Cluster II (RST $9^{\mathrm{T}}$ and RST 27) were closest to Bifidobacterium callitrichos DSM $23973^{\mathrm{T}}(99.2 \%$ and $99.7 \%$, respectively), strains in Cluster III (RST 7 and RST 11) were closest to Bifidobacterium tissieri DSM $100201^{\mathrm{T}}$ (99.7\% and 99.2\%), strain in Cluster IV (RST 19) was closest to Bifidobacterium reuteri DSM $23975^{\mathrm{T}}$ (98.9\%), strain in Cluster V (RST 17) was closest to Bifidobacterium myosotis DSM $100196^{\mathrm{T}}$ (99.3\%) (Fig. 1).

In order to assess the genetic diversity of the eight strains as compared to the other currently recognized Bifidobacterium species, multilocus sequence analysis (MLSA) based on the concatenated five housekeeping genes (hsp60, rpoB, clpC, dnaJ, dnaG) was carried out. Thus, the phylogenetic location of the novel strains was verified by the analysis of genes which have proven to be discriminative for the classification of the genus Bifidobacterium $[10,30]$.

For this purpose, a phylogenetic tree for 79 bifidobacterial type strains was constructed by joining the five coding sequences in the following order: hsp60 (662 bp), rpoB (500 bp), clpC (720 bp), dna (477 bp) and dnaG (992 bp). The resulting in-frame concatenated gene sequences ( $3154 \mathrm{bp}$ ) were aligned with the MAFFT program at CBRC (http://mafft.cbrc.jp/alignment/software/) [9]. The evolutionary distances were computed by nucleotide model GTR CAT, and the phylogenetic tree was constructed by RaxML (version 8.2.7, maximum-likelihood method) [25] with Scardovia inopinata JCM $12537^{\mathrm{T}}$ as an outgroup. The statistical reliability of the tree was evaluated by bootstrap analysis (rapid hill climbing) of 1000 replicates. The visualization was performed with FigTree. 


\begin{tabular}{|ll}
\hline B.asteroides group & $-\mathrm{I}$ \\
$\square$ B.psychraerophilum group & $-\mathrm{II}$ \\
$\square$ B.adolescentis group & $-\mathrm{III}$ \\
$\square$ B.pseudolongum group & $-\mathrm{IV}$ \\
$\square$ B. bombi group & $-\mathrm{V}$ \\
$\square$ B. boum group & $-\mathrm{VI}$ \\
$\square$ B. pullorum group & $-\mathrm{VII}$ \\
$\square$ B. longum group & $-\mathrm{VIII}$ \\
$\square$ B. bifidum group & $-\mathrm{IX}$ \\
\hline
\end{tabular}

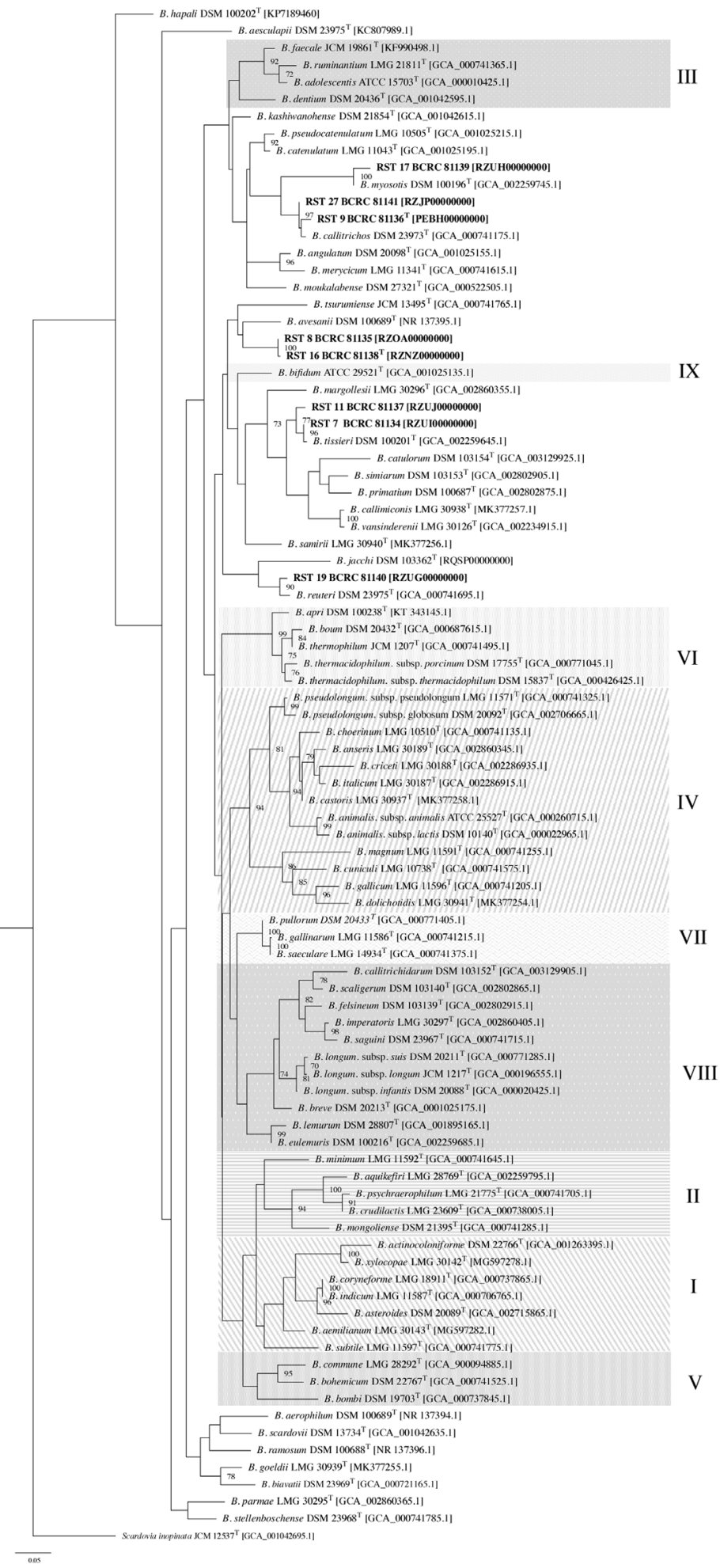

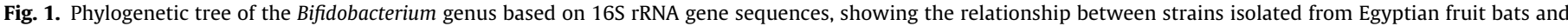

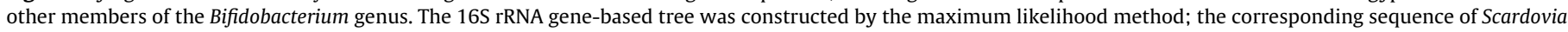
inopinata JCM $12537^{\mathrm{T}}$ was used as outgroup. Bootstrap percentages above 70 are shown at node points, based on 1000 replicates of the phylogenetic tree.

The MLSA analysis confirmed the close phylogenetic relatedness with the nearest neighbours of all the strains (Fig. 2).

Furthermore, the level of similarity for the partial housekeeping gene sequences of strains in relation to the type strains of their closest phylogenetic relatives was calculated using EMBOSS Water web-based program (https://www.ebi.ac.uk/Tools/ psa/emboss_water/nucleotide.html): the values of similarity for the hsp60, rpoB, clpC, dna and $d n a \mathrm{G}$ gene sequences were calculated and reported in Supplementary Table S1.

The genome of all 8 strains was decoded through a next generation sequencing (NGS) approach, using a MiSeq platform (Illumina) at BioFab Research (Roma, Italy). The generated data were depleted 

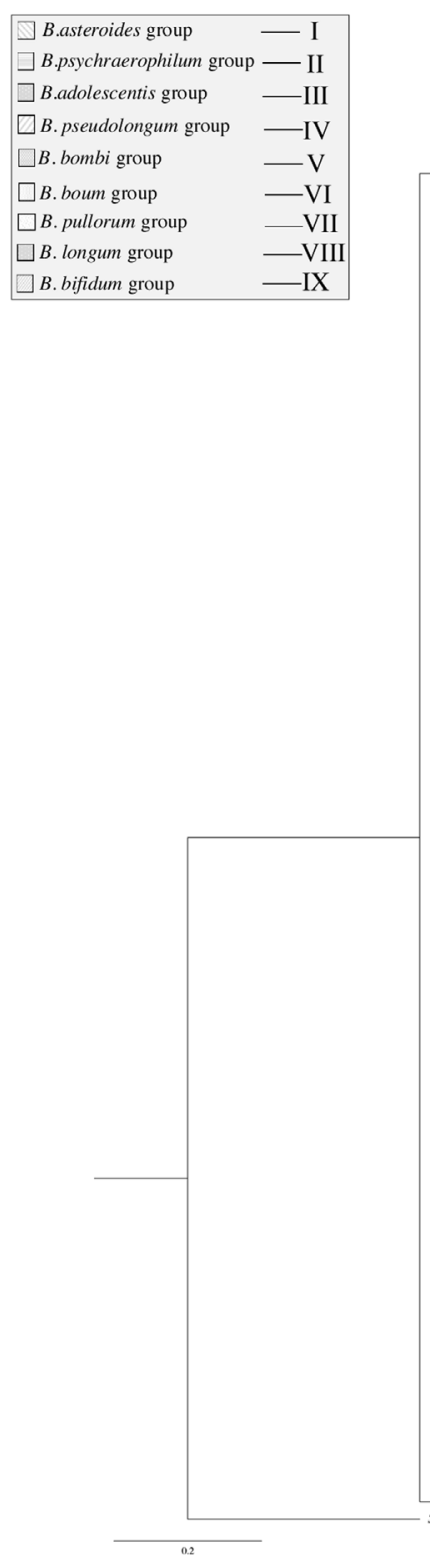

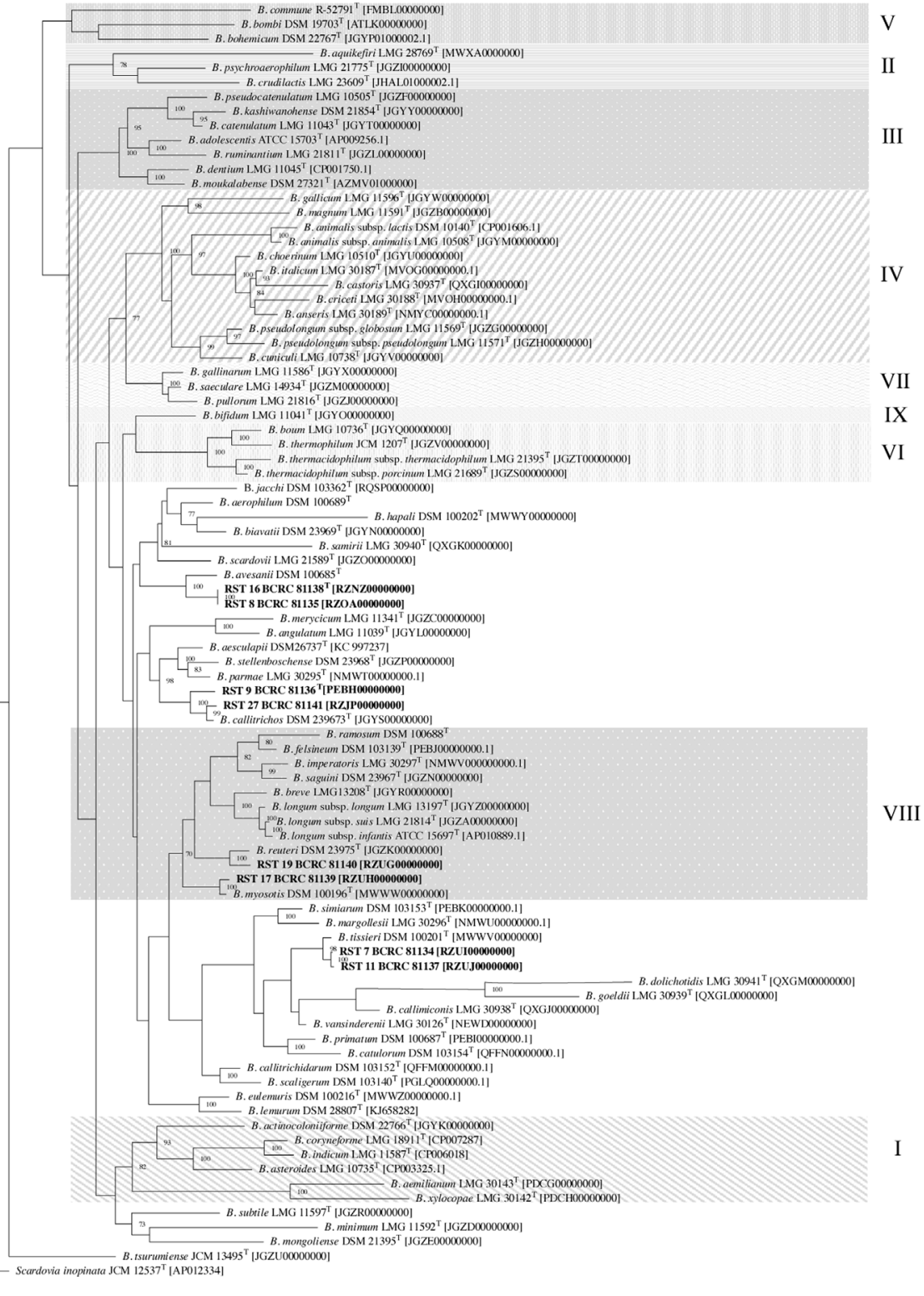

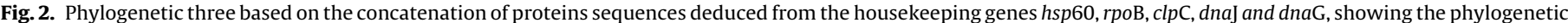

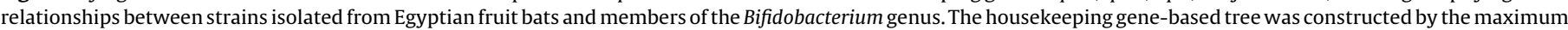

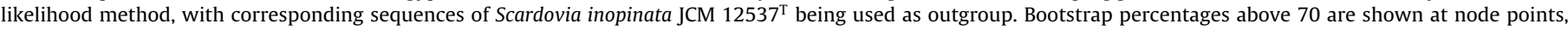
based on 1000 replicates of the phylogenetic tree.

of low quality reads using FASTQ/A Trimmer in FASTX-toolkit (http://hannonlab.cshl.edu/fastx_toolkit/), assembled by SPADES version 3.13.0 [29] and annotated through DFAST program [26].

The draft genome size of strains RST 8 and RST $16^{\mathrm{T}}$ (Cluster I), RST $9^{\mathrm{T}}$ and RST 27 (Cluster II), RST 7 and RST 11 (Cluster III), RST 19 (Cluster IV) and RST 17 (Cluster V) ranged between 2.80 and $3.28 \mathrm{Mbp}$ as indicated in Table 1 together with their other genomic features. In silico analysis of all the sequenced genomes allowed the estimation of their $\mathrm{G}+\mathrm{C}$ contents, which ranged from 60.39 to $64.55 \mathrm{~mol} \%$, falling in the range indicated for the genus Bifidobacterium, i.e., 52-67 mol\%. The project outline has been submitted to the BioProject PRJNA415181 and the GenBank accession numbers were reported in Table 1.

In order to reconfirm the above phylogenetic analysis, we also constructed the phylogenetic tree based on the core genome of Bifidobacterium spp. Total 76 type strains of Bifidobacterium were annotated with the DFAST program [26], and 355 orthologous genes were identified as the core retained in all genomes. The amino acid sequences of core genes from each genome were concatenated and aligned using the MAFFT program (version 7.313) [9]. The alignments were trimmed using trimAl with -automated1 option [2].

The phylogenomic tree (Fig. 3) based on the core genome (355 genes) confirmed the positioning of the eight isolated strains within the genus Bifidobacterium as observed in the phylogenetic analyses based on 16S rRNA and housekeeping gene sequences (Figs. 1 and 2).

In addition, the genetic similarity at genomic level of RST $16^{\mathrm{T}}$ and RST 8 (Cluster I), RST $9^{\mathrm{T}}$ and RST 27 (Cluster II), RST 7 and RST 11 (Cluster III), RST 19 (Cluster IV) and RST 17 (Cluster V) isolates with respect the other currently recognized bifidobacterial species was evaluated based on average nucleotide identity (ANI) analysis by using the web server JSpeciesWS (http://jspecies. ribohost.com/jspeciesws/). This analysis (Supplementary Table S2) showed that the highest sequence identity value between RST $16^{\mathrm{T}}$ 
Table 1

Genomic and phylogenetic features of novel bifidobacterial strains isolated from the Egyptian bats.

\begin{tabular}{|c|c|c|c|c|c|c|c|c|}
\hline Strain & RST $16^{\mathrm{T}}$ & RST 8 & RST $9^{\mathrm{T}}$ & RST 7 & RST 11 & RST 17 & RST 19 & RST 27 \\
\hline Accessionnumber & RZNZ00000000 & RZOA00000000 & РЕВН00000000 & RZUI00000000 & RZUJ00000000 & RZUH00000000 & RZUG00000000 & RZJP00000000 \\
\hline GC content & $64.20 \%$ & $64.20 \%$ & $64.55 \%$ & $60.96 \%$ & $60.76 \%$ & $63.16 \%$ & $60.39 \%$ & $63.58 \%$ \\
\hline Contigs & 49 & 74 & 37 & 49 & 46 & 60 & 80 & 11 \\
\hline Length (bp) & 3075992 & 3067389 & 3053799 & 3032244 & 2986510 & 3275217 & 2833112 & 2797830 \\
\hline No. of ORF & 2577 & 2594 & 2712 & 2526 & 2540 & 2759 & 2436 & 2320 \\
\hline tRNA & 57 & 62 & 64 & 61 & 62 & 62 & 59 & 61 \\
\hline rRNA & 5 & 3 & 5 & 2 & 2 & 5 & 3 & 3 \\
\hline Coverage & 118 & 165 & 189 & 107 & 145 & 209 & 140 & 155 \\
\hline
\end{tabular}

and RST 8 was $78.66 \%$ and $78.49 \%$ when compared to the chromosome sequence of Bifidobacterium reuteri DSM $23975^{\mathrm{T}}$, the highest sequence identity value between RST $9^{\mathrm{T}}$ and RST 27 when compared to Bifidobacterium callitrichos DSM $23973^{\mathrm{T}}$ were $89.43 \%$ and $96.06 \%$ respectively, the highest sequence identity value between RST 7 and RST 11 was $95.10 \%$ and $94.78 \%$ when compared to Bifidobacterium tissieri DSM $100201^{\mathrm{T}}$, the highest sequence identity value between RST 19 was $96.94 \%$ when compared to Bifidobacterium reuteri DSM $23975^{\mathrm{T}}$ and that of RST 17 was $95.98 \%$ when compared to Bifidobacterium myosotis DSM $100196^{\mathrm{T}}$.

ANI with closest neighbours supported an independent phylogenetic position, i.e. ANI value of $\leq 95 \%$ for strains in Clusters I (RST $16^{\mathrm{T}}$ and RST 8) and in Cluster II (RST 9 ${ }^{\mathrm{T}}$ ). Therefore, strain RST $16^{\mathrm{T}}$ and strain RST $9^{\mathrm{T}}$ were selected as the type strains of the two novel species. However, RST $9^{\mathrm{T}}$ showed high sequence similarity with $B$. callitrichos DSM $23973^{\mathrm{T}}$ for their $16 \mathrm{~S}$ rRNA gene sequences.

To verify their low ANI values, an in silico DDH (isDDH) was also carried out using Genome-to-Genome Distance Calculator (GGDC) version 2.1 formula 2 , the most accurate known tool for calculating DDH-analogous values, developed at DSMZ and available at www. ggdc.dsmz.de. The threshold value of $\leq 70 \%$ is generally accepted for separated prokaryote species [15]. When comparing strains RST $16^{\mathrm{T}}$ and RST $9^{\mathrm{T}}$ with their nereast neighbours, the values achieved were 32.5 and $42.1 \%$, respectively. The analysis was also performed among the 8 isolated strains and obtained results were in the range of $65.2-79.5 \%$ (Supplementary Table S3).

Evaluation of the above phylogenetic relationships of RST $16^{\mathrm{T}}$ and RST 8, RST 9 ${ }^{\mathrm{T}}$, RST 7 and RST 11, RST 19, RST 17 and RST 27 isolates with respect to other (sub)species clearly recognized two putative novel species, namely RST $16^{\mathrm{T}}$ and RST $9^{\mathrm{T}}$.

Furthermore, this work describe the morphological, biochemical and molecular characterizations of the remaining strains placed on Clusters II, III, IV and V belonging to the known species B. callithri$\cos , B$. tissieri, B. myosotis and B. reuteri, respectively, all of which have been described as isolates from Rousettus aegyptiacus.

The eight strains, selected as representatives from identified clusters, showed rod-shaped cells, frequently forming filaments, with irregular contractions along the cells and bifurcations. They were cultivated under anaerobic conditions and maintained in TPY broth [24] pH 6.9, at $37^{\circ} \mathrm{C}$, unless indicated otherwise.

Morphological, cultural and biochemical characterization of the strains were performed at $37^{\circ} \mathrm{C}$ unless otherwise stated, as described previously [18].

The morphology of cells of strains RST $16^{\mathrm{T}}$ and RST $9^{\mathrm{T}}$, as revealed by phase-contrast microscopy, is shown in Fig. 4.

Optimal growth conditions of the strains were determined in TPY broth after $24 \mathrm{~h}$ of incubation at $37^{\circ} \mathrm{C}$ in anaerobic condition. Growth at $22,25,30,35,37,40,42,45,48^{\circ} \mathrm{C}$ was tested. Sensitivity to low pH was screened at 3.5, 4.0, 4.5, 5.0, 5.5, 6.0, 6.5, 7.0, and 7.5 values of $\mathrm{pH}$. The ability of the strains to grow under aerobic and microaerophilic conditions (CampyGen; Oxoid) was also verified in TPY broth after $48 \mathrm{~h}$ of incubation at $37^{\circ} \mathrm{C}$. Particularly, for strains RST $16^{\mathrm{T}}$, RST 8 and RST $9^{\mathrm{T}}$ best growth conditions were obtained in TPY broth pH 7 at $37^{\circ} \mathrm{C}$ and they were able to survive and grow in microaerophilic and in aerobic conditions. All results are showed in Table 2.

Haemolytic activity was determined in Columbia blood agar (Biolife) at $37^{\circ} \mathrm{C}$ under anaerobic conditions for $48 \mathrm{~h} \mathrm{[27].}$

Gram staining, motility assay, catalase and oxidase activities were performed as described previously [24].

Strains RST $16^{\mathrm{T}}$ and RST 8, RST $9^{\mathrm{T}}$, RST 7 and RST 11, RST 19, RST 17 and RST 27 and related species $B$. avesanii DSM $100685^{\mathrm{T}}, B$. reuteri DSM $23975^{\mathrm{T}}$, B. myosotis $100196^{\mathrm{T}}$, B. tissieri DSM $100201^{\mathrm{T}}$, and $B$. callitrichos DSM $23973^{\mathrm{T}}$ were also investigated for substrates utilization and enzymes production with API 50 CHL and Rapid ID 32 A test kits (BioMérieux). Results are summarized in Table 2.

Bifidobacteria and members of related genera possess fructose6-phosphate phosphoketolase (F6PPK), the enzyme degrading hexose via the F6PPK pathway, which is considered a taxonomic marker for identification of Bifidobacterium and related genera [15]. Detection of F6PPK activity was carried out according to the method described by Orban \& Patterson [26]. All studied strains possessed the F6PPK activity.

For analysis of amino acid composition, the cell-wall peptidoglycan of strains RST $16^{\mathrm{T}}$ and RST $9^{\mathrm{T}}$ was prepared and hydrolysed as described previously [6]. Cell-wall amino acids were analysed by HPLC (model LC-20AB; Shimadzu) equipped with a Wakopak wakosil-PTC column $(200 \times 4.0 \mathrm{~mm}$ i.d.; Wako Pure Chemical Industries), as their phenyl isothiocyanate derivatives (Wako). Amino acid isomers in the cell-wall hydrolysate were analysed as described previously using a liquid chromatographmass spectrometer (model LCMS-2020 and LC-20AB; Shimadzu) equipped with a Shim-Pack FC-ODS column $(150 \times 2.0 \mathrm{~mm}$ i.d.; Shimadzu) [20]. The peptidoglycan of strain RST16 ${ }^{\mathrm{T}}$ contained glutamic acid (Glu), serine (Ser), alanine (Ala) and ornithine (Orn) in a molar ratio of 4:1:2:1. Enantiomeric analysis of the peptidoglycan amino acids revealed the presence of L-Orn-L-Glu3-D -Ser-Glu3.

The peptidoglycan of strain RST $9^{\mathrm{T}}$ contained glutamic acid (Glu), alanine (Ala) ornithine (Orn) and lysine (Lys) in a molar ratio of $2: 2: 1: 1$. Enantiomeric analysis of the peptidoglycan amino acids revealed the presence of L-Orn(L-Lys)-D-Glu.

Whole-cell fatty acids were analysed as fatty acid methyl esters (FAMEs) with Sherlock phospholipid fatty acid software (midi). The cultures of all studied strains were incubated on MRS agar added with $0.05 \%$ cysteine plates at $37^{\circ} \mathrm{C}$ for $48 \mathrm{~h}$ under anaerobic conditions. FAMEs were extracted and prepared as described previously [23]. Results are shown in Table 3.

On the basis of the phenotypic and chemotaxonomic characterization as well as the molecular-based methods phylogenetic analysis based on the 16S rRNA gene sequences, MLSA based on the concatenated five housekeeping gene sequences, and the wholegenome-based sequence comparisons in silico, strains RST $16^{\mathrm{T}}$ and RST $9^{\mathrm{T}}$ were genetically and phenotypically discernible from the currently recognized species of bifidobacteria; thus, according to Minimal Standard guidelines [16], they represent two novel taxa for which the name Bifidobacterium vespertilionis sp. nov. and Bifidobacterium rousetti sp. nov. are proposed. 


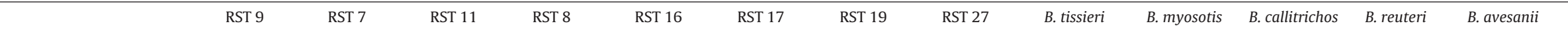

\section{Fermentation}

Glycerol

D-Arabinose

L-Arabinose

Ribose

D-Xylose

L-Xylose

Methyl- $\beta$-D-
xylopyranosid

Galactose

ructose

Mannose

Sorbose

Rhamnos

Inositol

Mannitol

Sorbitol

Methyl- $\alpha$-D-

mannopyranoside

Methyl- $\alpha$-D-

glucopyranoside

$\mathrm{N}$-Acetyl glucosamine

Amygdalin

Arbutin

Aesculin

Salicin

Cellobios

Maltose

Lactose

Melebiose

Sucrose

Trehalose

Inulin

Melezitose

Raffinose

Starch

Glycogen

Xylitol

Gentiobiose

Turanose

Lyxose

L-Fucose

2-keto-gluconate

5-keto-gluconate

5-keto-gluconate

Urease

L-arginine dihydrolase

$\alpha$-Glucosidase

$\beta$-Glucosidase

$\alpha$-Arabinosidase

$\beta$-Glucuronidase

$N$-Acetyl- $\beta$ -

$\begin{array}{ll}\text { RST } 9 & \text { RST } 7\end{array}$

$\begin{array}{llll}\text { RST } 8 & \text { RST 16 } & \text { RST 17 } & \text { RST 19 }\end{array}$

glucosaminidas

Glutamic acid

decarboxylase 


\begin{tabular}{|c|c|c|c|c|c|c|c|c|c|c|c|c|c|}
\hline ALkaline phosphatase & - & $\mathrm{w}$ & + & + & + & - & - & + & - & - & - & + & + \\
\hline Arginine arylamidase & + & + & + & + & + & + & + & + & - & - & + & + & + \\
\hline Leucyl glycine arylamidase & - & - & - & - & + & + & + & + & + & + & $\mathrm{w}$ & $\mathrm{w}$ & + \\
\hline Phenylalanine arylamidase & + & + & + & + & + & + & + & + & + & + & + & $\mathrm{w}$ & + \\
\hline Leucine arylamidase & + & $\mathrm{w}$ & + & + & + & + & + & + & + & + & + & + & + \\
\hline $\begin{array}{l}\text { Pyroglutamic acid } \\
\text { arylamidase }\end{array}$ & - & - & - & + & + & - & - & - & - & - & - & - & + \\
\hline Tyrosine arylamidase & + & $\mathrm{w}$ & + & + & + & + & - & + & + & + & + & + & + \\
\hline AlanineaArylamidase & + & - & - & - & + & + & + & + & + & + & $\mathrm{w}$ & - & + \\
\hline Glycine arylamidase & + & + & + & $\mathrm{w}$ & + & + & + & + & + & + & $\mathrm{w}$ & - & + \\
\hline Histidine arylamidase & + & + & + & + & + & + & + & + & + & + & + & + & + \\
\hline $\begin{array}{l}\text { Glutamyl glutamic acid } \\
\text { arylamidase }\end{array}$ & - & - & - & - & W & - & - & - & - & - & - & - & w \\
\hline Serine arylamidase & + & + & + & + & + & + & + & + & - & + & $\mathrm{w}$ & - & + \\
\hline $\begin{array}{l}\text { Temperature range for } \\
\text { growth }\end{array}$ & $22-48^{\circ} \mathrm{C}$ & $22-48^{\circ} \mathrm{C}$ & $22-48^{\circ} \mathrm{C}$ & $22-48^{\circ} \mathrm{C}$ & $22-48^{\circ} \mathrm{C}$ & $22-48^{\circ} \mathrm{C}$ & $22-48^{\circ} \mathrm{C}$ & $22-48^{\circ} \mathrm{C}$ & $20-44^{\circ} \mathrm{C}$ & $20-48^{\circ} \mathrm{C}$ & $26-42^{\circ} \mathrm{C}$ & $35-37^{\circ} \mathrm{C}$ & $25-50^{\circ} \mathrm{C}$ \\
\hline Optimum temperature & $37^{\circ} \mathrm{C}$ & $37^{\circ} \mathrm{C}$ & $37^{\circ} \mathrm{C}$ & $37^{\circ} \mathrm{C}$ & $37^{\circ} \mathrm{C}$ & $37^{\circ} \mathrm{C}$ & $37^{\circ} \mathrm{C}$ & $37^{\circ} \mathrm{C}$ & $35^{\circ} \mathrm{C}$ & $42^{\circ} \mathrm{C}$ & $37^{\circ} \mathrm{C}$ & $37^{\circ} \mathrm{C}$ & $40^{\circ} \mathrm{C}$ \\
\hline $\mathrm{pH}$ range for growth & $3.5-7.5$ & $3.5-7.5$ & $3.5-7.5$ & $3.5-7.5$ & $3.5-7.5$ & $3.5-7.5$ & $3.5-7.5$ & $3.5-7.5$ & $5.5-7.5$ & $4-7.5$ & $5.0-8.0$ & $5.0-7.0$ & $4.0-7.5$ \\
\hline Optimum pH & 7.0 & 7.0 & 7.0 & 7.0 & 7.0 & 7.0 & 7.0 & 7.0 & 6.5 & 7.0 & 7.0 & 7.0 & 6.0 \\
\hline DNA GC content (mol\%) & $64.5^{\mathrm{a}}$ & $60.96^{\mathrm{a}}$ & $60.76^{\mathrm{a}}$ & $64.20^{\mathrm{a}}$ & $64.20^{\mathrm{a}}$ & $63.16^{a}$ & $60.39^{a}$ & $63.58^{\mathrm{a}}$ & $63.7^{\mathrm{a}}$ & $65.1^{\mathrm{a}}$ & $64.3^{\mathrm{a}}$ & $61.3^{\mathrm{b}}$ & $65.9^{c}$ \\
\hline Peptidoglycan type & $\begin{array}{l}\text { L-Orn(L- } \\
\text { Lys)-D-Glu }\end{array}$ & $\begin{array}{l}\text { L-Glu-L- } \\
\text { Ala-L-Lys }\end{array}$ & $\begin{array}{l}\text { L-Glu-L- } \\
\text { Ala-L-Lys }\end{array}$ & $\begin{array}{l}\text { L-Orn-L- } \\
\text { Glu3-D-Ser }\end{array}$ & $\begin{array}{l}\text { L-Orn-L- } \\
\text { Glu3-D-Ser }\end{array}$ & $\begin{array}{l}\text { L-Glu-L- } \\
\text { Ala-L-Lys }\end{array}$ & L-Lys-Gly & $\begin{array}{l}\text { L-Lys(L- } \\
\text { Orn)-D-Asp }\end{array}$ & $\begin{array}{l}\text { L-Glu-L- } \\
\text { Ala-L-Lys }\end{array}$ & $\begin{array}{l}\text { L-Glu-L- } \\
\text { Ala-L-Lys }\end{array}$ & $\begin{array}{l}\text { L-Lys(L-Orn)- } \\
\text { D-Asp }\end{array}$ & L-Lys-Gly & $\begin{array}{l}\text { L-Orn(Lys)-D- } \\
\text { Ser-D-Glu. }\end{array}$ \\
\hline
\end{tabular}

+, positive; -, negative; w, weakly positive. All strains ferm

a Data are from this study.

b Data are from Endo et al. [4].

data are from Michelini et al. [16]. 


\begin{tabular}{|ll|}
\hline$\square$ B.asteroides group & $-\mathrm{I}$ \\
$\square$ B.psychraerophilum group & $-\mathrm{II}$ \\
$\square$ B.adolescentis group & $-\mathrm{III}$ \\
$\square$ B.pseudolongum group & $-\mathrm{IV}$ \\
$\square$ B. bombi group & $-\mathrm{V}$ \\
$\square$ B. boum group & - VI \\
$\square$ B. pullorum group & - VII \\
$\square$ B. longum group & - VIII \\
$\square$ B. bifidum group & $-\mathrm{IX}$ \\
\hline
\end{tabular}

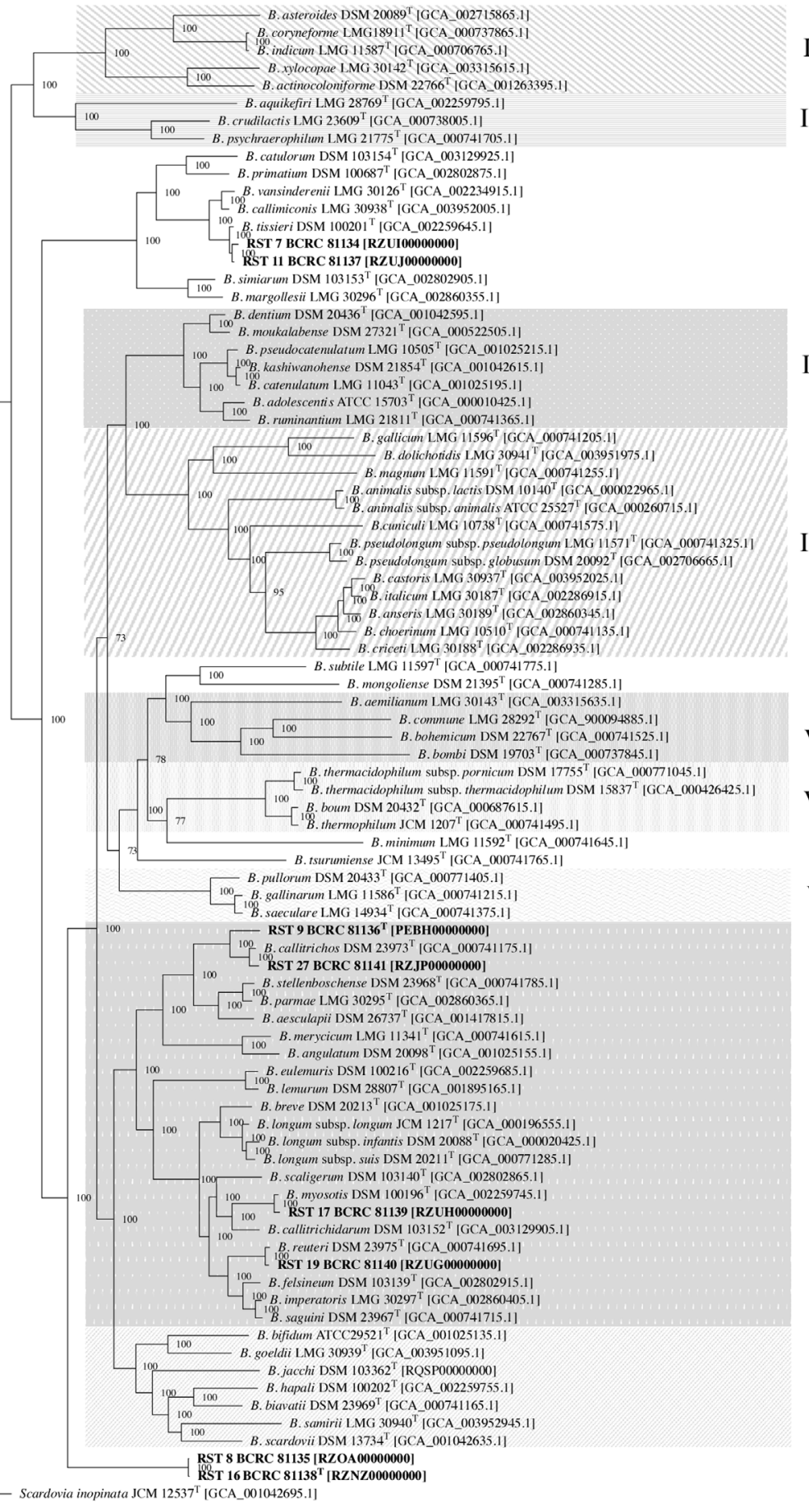

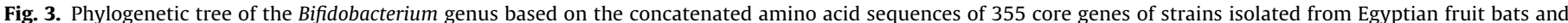

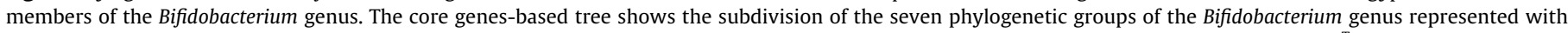

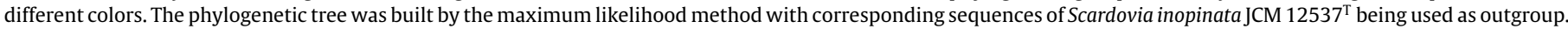
Bootstrap percentages above 70 are shown at node points, based on 1000 replicates of the phylogenetic tree.

\section{Description of Bifidobacterium vespertilionis sp. nov}

Bifidobacterium vespertilionis (ve.sper.ti.lio'nis. L. gen. n. vespertilionis of a bat).

Cells are Gram-positive-staining, non-motile, asporogenous, non-haemolytic, F6PPK-positive, catalase- and oxidase-negative, indole-negative, and when growing in TPY broth are rods of various shapes forming a branched structure with ' $\mathrm{Y}$ ' at both sides. The well isolated colonies grown on the surface of TPY agar under anaerobic conditions are white, opaque, smooth and circular with entire edges, while the embedded colonies are lensshaped or elliptical. Colonies reach $1.0-2.0 \mathrm{~mm}$ in diameter after 3 days of incubation. Cells can grow in the range $22-48^{\circ} \mathrm{C}$. Cells grow at $\mathrm{pH} 4.0-7.5$. Optimal conditions of growth occur at $\mathrm{pH} 7$ and $37^{\circ} \mathrm{C}$. Using API $50 \mathrm{CHL}$ system acids are produced from D-glucose, L-arabinose, lactose, D-fructose, D-mannitol, Dmannose, maltose, sucrose, raffinose, turanose, D-xylose, gluconic acid, and produced weakly from D-galactose, D-mannose, Methyl- 


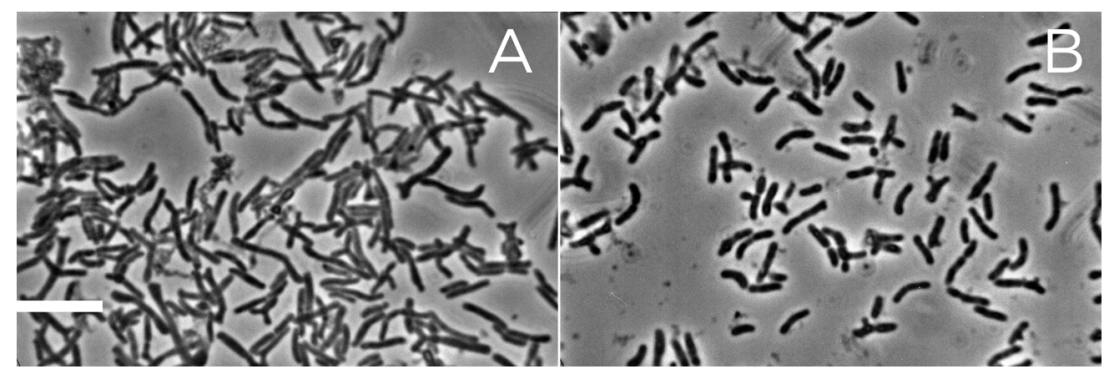

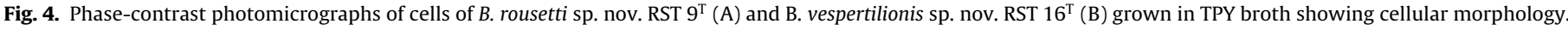
Bar, $10 \mu \mathrm{m}$.

Table 3

Cellular fatty acid profiles of strains isolated from the Egyptian fruit bat.

\begin{tabular}{|c|c|c|c|c|c|c|c|c|}
\hline \multirow[t]{2}{*}{ Fatty acid } & \multicolumn{2}{|l|}{ Cluster I } & \multicolumn{2}{|l|}{ Cluster II } & \multicolumn{2}{|l|}{ Cluster III } & \multirow{2}{*}{$\begin{array}{l}\text { Cluster IV } \\
\text { RST } 19\end{array}$} & \multirow{2}{*}{$\begin{array}{l}\text { Cluster V } \\
\text { RST } 17\end{array}$} \\
\hline & RST 8 & RST $16^{\mathrm{T}}$ & RST $9^{\mathrm{T}}$ & RST 27 & RST 7 & RST 11 & & \\
\hline C16:0 & $51.15 \pm 0.30$ & $39.02 \pm 0.20$ & $34.82 \pm 1.04$ & $39.89 \pm 0.30$ & $56.21 \pm 0.67$ & $43.46 \pm 0.54$ & $24.29 \pm 0.43$ & $\mathbf{3 7 . 7 8} \pm \mathbf{0 . 2 7}$ \\
\hline $\mathrm{C} 14: 0$ & $5.80 \pm 0.12$ & $\mathbf{1 6 . 3} \pm \mathbf{0 . 4 7}$ & $24.96 \pm 1.75$ & $23.07 \pm 0.72$ & $10.57 \pm 0.39$ & $11.80 \pm 0.45$ & $21.68 \pm 0.62$ & $19.68 \pm 0.17$ \\
\hline $\mathrm{C} 18: 1 \omega 9 \mathrm{c}$ & $18.15 \pm 0.64$ & $8.14 \pm 0.2$ & $8.17 \pm 0.71$ & $8.74 \pm 0.34$ & & $11.13 \pm 0.28$ & $15.15 \pm 0.62$ & $7.20 \pm 0.34$ \\
\hline $\mathrm{C} 16: 1 \omega 9 \mathrm{c}$ & $2.45 \pm 0.10$ & $6.07 \pm 0.56$ & $2.83 \pm 0.10$ & $2.15 \pm 0.03$ & $1.62 \pm 0.31$ & $1.54 \pm 0.16$ & $8.18 \pm 0.23$ & $3.30 \pm 0.10$ \\
\hline C18:0 & $1.99 \pm 0.01$ & $1.64 \pm 0.04$ & $1.30 \pm 0.07$ & $2.04 \pm 0.07$ & $9.76 \pm 0.29$ & $6.15 \pm 0.29$ & & $1.64 \pm 0.01$ \\
\hline $\mathrm{C} 12: 0$ & & $1.35 \pm 0.02$ & $1.85 \pm 0.30$ & $1.74 \pm 0.12$ & $1.84 \pm 0.10$ & & $2.84 \pm 0.20$ & $1.87 \pm 0.09$ \\
\hline $\mathrm{C} 13: 1$ at $12-13$ & & $2.19 \pm 0.30$ & $2.03 \pm 0.26$ & $1.65 \pm 0.14$ & $2.19 \pm 0.01$ & $1.10 \pm 0.07$ & & $2.32 \pm 0.05$ \\
\hline C19:0 iso I & & & & & $2.37 \pm 0.05$ & $1.14 \pm 0.04$ & & \\
\hline $\mathrm{C} 20: 0$ & & & & & $1.91 \pm 0.23$ & & & \\
\hline $\mathrm{C} 17: 1 \omega 9 \mathrm{c}$ & & & & & $1.49 \pm 0.09$ & & & \\
\hline C10:0 & & & & & $1.26 \pm 0.08$ & & & \\
\hline \multicolumn{9}{|c|}{ Summed features* } \\
\hline 1 & $2.30 \pm 0.07$ & $6.85 \pm 0.44$ & $6.53 \pm 0.39$ & $5.34 \pm 0.16$ & $6.68 \pm 0.29$ & $3.32 \pm 0.22$ & $2.74 \pm 0.09$ & $6.86 \pm 0.26$ \\
\hline 4 & $1.49 \pm 0.09$ & & & & $2.41 \pm 0.08$ & $1.55 \pm 0.10$ & & \\
\hline 7 & $12.53 \pm 0.40$ & $13.80 \pm 0.90$ & $11.38 \pm 1.00$ & $10.05 \pm 0.34$ & & $13.62 \pm 0.10$ & $18.19 \pm 0.91$ & $13.70 \pm 0.28$ \\
\hline 8 & $1.76 \pm 0.14$ & $2 . .34 \pm 0.29$ & $3.12 \pm 0.11$ & $2.26 \pm 0.06$ & & $3.27 \pm 0.30$ & $2.12 \pm 0.03$ & $2.44 \pm 0.16$ \\
\hline
\end{tabular}

In bold the main fatty acids produced.

$\alpha$-D-glucopyranoside, starch, 5-ketogluconate but not from other carbohydrates. Activity was observed for $\alpha$ - and $\beta$-galactosidase, $\alpha$-glucosidase, $\alpha$-arabinosidase, $N$-acetyl- $\beta$-glucosaminidase, alkaline phosphatase, arginine arylamidase, proline arylamidase, leucyl glycine arylamidase, phenylalanine arylamidase, leucine arylamidase, pyroglutamic acid arylamidase, tyrosine arylamidase, alanine arylamidase, glycine arylamidase, histidine arylamidase, serine arylamidase. Activity was also observed weakly for arginine dihydrolase, $\beta$-glucosidase, glutamyl glutamic acid arylamidase. Aesculine is not hydrolysed. No reduction of nitrates was recognized. Cells are positive for urease. The peptidoglycan type is L-Orn-L-Glu3-D-Ser.

The type strain RST $16^{\mathrm{T}}\left(=\mathrm{BCRC} 81138^{\mathrm{T}}=\right.$ NBRC $113380^{\mathrm{T}}=\mathrm{DSM}$ $106025^{\mathrm{T}}$ ) was isolated from the faeces of the Egyptian fruit bat Rousettus aegyptiacus. The DNA G + C content of the type strain is $64.20 \mathrm{~mol} \%$.

The taxonumber of digital protologue is TA00874.

\section{Description of Bifidobacterium rousetti sp. nov}

Bifidobacterium rousetti (rou.set'ti. N.L. gen. n. rousetti of Rousettus aegyptiacus, the Egyptian fruit bat).

Cells are Gram-positive-staining, non-motile, asporogenous, non-haemolytic, F6PPK-positive, catalase- and oxidase-negative, indole-negative, and when growing in TPY broth are rods of various shapes forming a branched structure with ' $Y$ ' at both sides. The well isolated colonies grown on the surface of TPY agar under anaerobic conditions are white, opaque, smooth and circular with entire edges, while the embedded colonies are lens-shaped or elliptical. Colonies reach $1.0-2.0 \mathrm{~mm}$ in diameter after 3 days of incubation. Cells can grow in the range $22-48^{\circ} \mathrm{C}$. Cells grow at $\mathrm{pH} 4.0-7.5$.
Optimal conditions of growth occur at $\mathrm{pH} 7$ and $37^{\circ} \mathrm{C}$. Using API 50 CHL system acids are produced from D-glucose, L-arabinose, Dfructose, D-mannitol, D-mannose, raffinose, turanose, D-galactose, sorbitol, gluconic acid and produced weakly from D-ribose, maltose, lactose, starch and 5-ketogluconate but not from other carbohydrates. Activity was observed for $\alpha$ - and $\beta$-galactosidase, $\alpha$-glucosidase, $\alpha$-arabinosidase, glutamic acid decarboxylase, arginine arylamidase, proline arylamidase, phenylalanine arylamidase, leucine arylamidase, tyrosine arylamidase, alanine arylamidase, glycine arylamidase, histidine arylamidase, serine arylamidase. Activity was also observed weakly for L-arginine dihydrolase, $\beta$ glucosidase. Aesculine is hydrolysed. No reduction of nitrates was recognized. Cells are positive for urease. The peptidoglycan type is L-Orn(L-Lys)-D-Glu.

The type strain RST $9^{\mathrm{T}}\left(=\mathrm{BCRC} 81136^{\mathrm{T}}=\mathrm{NBRC} 113378^{\mathrm{T}}=\mathrm{DSM}\right.$ $106027^{\mathrm{T}}$ ) was isolated from the faeces of the Egyptian fruit bat Rousettus egyptiacus. The DNA G + C content of the type strain is $64.55 \mathrm{~mol} \%$.

The taxonumber of digital protologue is TA00875.

\section{GenBank accession number}

The GenBank accession number for the 16S rRNA partial gene sequence for the novel isolated strains RST 7, RST 8, RST $9^{\mathrm{T}}$, RST 11, RST $16^{\mathrm{T}}$, RST 17, RST 19, RST 27 are MK722390, MK722393, MK722392, MK722391, MK722394, MK722395, MK722396, MK722397, respectively.

The GenBank accession numbers for the genomes of the novel isolated strains RST 7, RST 8, RST $9^{\mathrm{T}}$, RST 11, RST $16^{\mathrm{T}}$, RST 17 , RST 19, RST 27 are RZUI00000000, RZOA00000000, PEBH00000000, 
RZUJ00000000, RZNZ00000000, RZUH00000000, RZUG00000000, RZJP00000000, respectively.

The deposit accession numbers for the isolated strains are the following: RST 7 (BCRC 81134, NBRC 113376, DSM 106022), RST 8 (BCRC 81135, NBRC 113377); RST 11 (BCRC 81136, NBRC 113379, DSM 106024); RST 17 (BCRC 81139, NBRC 113381, DSM 106026); RST 19 (BCRC 81140, NBRC 113382, DSM 106027); RST 27 (BCRC 81141, NBRC 113383, DSM 106028)

\section{Acknowledgements}

Computational analysis was performed on the NIG supercomputer at The Research Organization of Information and Systems (ROIS). The travel cost was supported by SOKENDAI Short-term Research Abroad \& long-term Internship Program 2018. This work was partially supported by JSPS KAKENHI (17K19248) in Japan.

\section{Appendix A. Supplementary data}

Supplementary material related to this article can be found, in the online version, at doi:https://doi.org/10.1016/j.syapm.2019. 126017.

\section{References}

[1] Banskar, S., Mourya, D.T., Shouche, Y.S. (2016) Bacterial diversity indicates dietary overlap among bats of different feeding habits. Microbiol. Res. 182, 99-108, http://dx.doi.org/10.1016/J.MICRES.2015.10.006.

[2] Capella-Gutierrez, S., Silla-Martinez, J.M., Gabaldon, T. (2009) trimAl: a tool for automated alignment trimming in large-scale phylogenetic analyses. Bioinformatics 25 (15), 1972-1973, http://dx.doi.org/10.1093/bioinformatics/btp348.

[3] Cavalli-Sforza, L.L., Edwards, A.W.F. (1967) Phylogenetic analysis. Models and estimation procedures. Evolution (N. Y). 21 (3), 550-570.

[4] Endo, A., Futagawa-Endo, Y., Schumann, P., Pukall, R., Dicks, L.M.T. (2012) Bifidobacterium reuteri sp. nov., Bifidobacterium callitrichos sp. nov., Bifidobacterium saguini sp. nov., Bifidobacterium stellenboschense sp. nov. and Bifidobacterium biavatii sp. nov. isolated from faeces of common marmoset (Callithrix jacchus) and red. Syst. Appl. Microbiol 35 (2), 92-97, http://dx.doi.org/10.1016/j.syapm. 2011.11.006.

[5] Fujita, M.S., Tuttle, M.D. (1991) Flying foxes (Chiroptera: Pteropodidae): threatened animals of key ecological and economic importance. Conserv. Biol. 5 (4), 455-463, http://dx.doi.org/10.1111/j.1523-1739.1991.tb00352.x.

[6] Hamada, M., Yamamura, H., Komukai, C., Tamura, T., Suzuki, K., Hayakawa, M. (2012) Luteimicrobium album sp. nov., a novel actinobacterium isolated from a lichen collected in Japan, and emended description of the genus Luteimicrobium. J. Antibiot. (Tokyo) 65 (8), 427-431, http://dx.doi.org/10.1038/ja.2012.45.

[7] Hughes, G.M., Leech, J., Puechmaille, S.J., Lopez, J.V., Teeling, E.C. (2018) Is there a link between aging and microbiome diversity in exceptional mammalian longevity? PeerJ 6, e4174, http://dx.doi.org/10.7717/peerj.4174.

[8] Jones, G., Teeling, E.C., Rossiter, S.J. (2013) From the ultrasonic to the infrared: molecular evolution and the sensory biology of bats. Front. Physiol. 4, 117, http://dx.doi.org/10.3389/fphys.2013.00117.

[9] Katoh, K., Standley, D.M. (2013) MAFFT multiple sequence alignment software version 7: improvements in performance and usability. Mol. Biol. Evol. 30 (4), 772-780, http://dx.doi.org/10.1093/molbev/mst010.

[10] Kim, B.J., Kim, H.-Y., Yun, Y.-J., Kim, B.-J., Kook, Y.-H. (2010) Differentiation of Bifidobacterium species using partial RNA polymerase \{beta\}-subunit (rpoB) gene sequences. Int. J. Syst. Evol. Microbiol. 60 (Pt 12), 2697-2704, http://dx. doi.org/10.1099/ijs.0.020339-0.

[11] Kolodny, O., Weinberg, M., Reshef, L., Harten, L., Hefetz, A., Gophna, U., Feldman, M.W., Yovel, Y. (2019) Coordinated change at the colony level in fruit bat fur microbiomes through time. Nat. Ecol. Evol. 3 (1), 116-124, http://dx.doi.org/ 10.1038/s41559-018-0731-z.
[12] Kolodny, O., Weinberg, M., Reshef, L., Harten, L., Hefetz, A., Gophna, U., Feldman, M.W., Yovel, Y. (2017) Who is the host of the host-associated microbiome? Colony-level dynamics overshadow individual-level characteristics in the fur microbiome of a social mammal, the Egyptian fruit-bat. BioRxiv, 232934, http:/ dx.doi.org/10.1101/232934.

[13] Kultzer, E. (1979) Physiological ecology and geographical range in the fruiteating cave bat genus Rousettus Gray 1821-a review. Bonner Zool. Beiträge 30, 233-275.

[14] McCracken, G.F., Westbrook, J.K., Brown, V.A., Eldridge, M., Federico, P., Kunz, T.H. (2012) Bats track and exploit changes in insect pest populations. PLoS One 7 (8), e43839, http://dx.doi.org/10.1371/journal.pone.0043839.

[15] Meier-Kolthoff, J.P., Auch, A.F., Klenk, H.-P., Göker, M. (2013) Genome sequencebased species delimitation with confidence intervals and improved distance functions. BMC Bioinform. 14(1), 60, http://dx.doi.org/10.1186/1471-2105-1460.

[16] Michelini, S., Modesto, M., Filippini, G., Spiezio, C., Sandri, C., Biavati, B., Pisi, A., Mattarelli, P. (2016) Bifidobacterium aerophilum sp. nov., Bifidobacterium avesanii sp. nov. and Bifidobacterium ramosum sp. nov.: three novel taxa from the faeces of cotton-top tamarin (Saguinus oedipus L.). Syst. Appl. Microbiol. 39 (4), 229-236, http://dx.doi.org/10.1016/j.syapm.2016.04.005.

[17] Modesto, M., Michelini, S., Sansosti, M.C., De Filippo, C., Cavalieri, D., Qvirist, L. Andlid, T., Spiezio, C., Sandri, C., Pascarelli, S., Sgorbati, B., Mattarelli, P. (2018) Bifidobacterium callitrichidarum sp. nov. from the faeces of the emperor tamarin (Saguinus imperator). Int. J. Syst. Evol. Microbiol. 68 (1), http://dx.doi.org/10. 1099/ijsem.0.002472.

[18] Modesto, M., Michelini, S., Stefanini, I., Ferrara, A., Tacconi, S., Biavati, B., Mattarelli, P. (2014) Bifidobacterium aesculapii sp. nov., from the faeces of the baby common marmoset (Callithrix jacchus). Int. J. Syst. Evol. Microbiol. 64 (Part 8), http://dx.doi.org/10.1099/ijs.0.056937-0.

[19] Modesto, M., Puglisi, E., Bonetti, A., Michelini, S., Spiezio, C., Sandri, C., Sgorbati, B., Morelli, L., Mattarelli, P. (2018) Bifidobacterium primatium sp. nov. Bifidobacterium scaligerum sp. nov., Bifidobacterium felsineum sp. nov. and Bifidobacterium simiarum sp. nov.: four novel taxa isolated from the faeces of the cotton top tamarin (Saguinus oedipus) and the emperor tamari. Syst. Appl. Microbiol. 41 (6), 593-603, http://dx.doi.org/10.1016/J.SYAPM.2018.07.005.

[20] Nozawa, Y., Sakai, N., Arai, K., Kawasaki, Y., Harada, K. (2007) Reliable and sensitive analysis of amino acids in the peptidoglycan of actinomycetes using the advanced Marfey's method. J. Microbiol. Methods 70 (2), 306-311, http://dx. doi.org/10.1016/j.mimet.2007.05.003.

[21] Rada, V., Sirotek, K., Petr, J. (1999) Evaluation of selective media for bifidobacteria in poultry and rabbit caecal samples. Zentralbl. Veterinarmed. B 46 (6), 369-373, http://dx.doi.org/10.1046/j.1439-0450.1999.00241.x.

[22] Rambaut, A. 2014 Figtree, a Graphical Viewer of Phylogenetic Trees, Available from: Http://Tree.Bio.Ed.Ac.Uk/Software/Figtree.

[23] Sasser, M. (1990) Identification of bacteria by gas chromatography of cellular fatty acids. USFCC Newsl 20, 16.

[24] Scardovi, V. (1986) Genus bifidobacterium. In: Sneath, P.H.A., Mair, N.S. M.E.S, J.G.H, (Eds.), Bergey's Manual of Systematic Bacteriology, Baltimore, pp. 1418-1434.

[25] Stamatakis, A. (2014) RAxML version 8: a tool for phylogenetic analysis and post-analysis of large phylogenies. Bioinformatics 30 (9), 1312-1313, http:// dx.doi.org/10.1093/bioinformatics/btu033.

[26] Tanizawa, Y., Fujisawa, T., Kanimuma, E., Nakamura, Y., Arita, M. (2016) DFAST and DAGA: web-based integrated genome annotation tools and resources. Biosci. Microbiota Food Health 35 (4), 173-184, http://dx.doi.org/10.12938/ bmfh.16-003.

[27] Teeling, E.C., Springer, M.S., Madsen, O., Bates, P., O’brien, S.J., Murphy, W.J. (2005) A molecular phylogeny for bats illuminates biogeography and the fossil record. Science 307 (5709), 580-584, http://dx.doi.org/10.1126/science. 1105113.

[28] Teeling, E.C., Vernes, S.C., Dávalos, L.M., Ray, D.A., Gilbert, M.T.P., Myers, E., Consortium, B. (2018) Bat biology, genomes, and the bat1k project: to generate chromosome-level genomes for all living bat species. Annu. Rev. Anim. Biosci. 6 (1), 23-46, http://dx.doi.org/10.1146/annurev-animal-022516-022811.

[29] Vengust, M., Knapic, T., Weese, J.S. (2018) The fecal bacterial microbiota of bats; Slovenia. PLoS One 13 (5), e0196728, http://dx.doi.org/10.1371/journal.pone. 0196728.

[30] Ventura, M., Canchaya, C., Del Casale, A., Dellaglio, F., Neviani, E., Fitzgerald, G.F., van Sinderen, D. (2006) Analysis of bifidobacterial evolution using a multilocus approach. Int. J. Syst. Evol. Microbiol. 56, 2783-2792, http://dx.doi.org/10.1099/ ijs.0.64233-0. 